Original paper UDC 1:28(045)

doi: $10.21464 / \mathrm{sp} 31204$

Received January $5^{\text {th }}, 2016$

\begin{abstract}
Ali Paya
University of Westminster, School of Social Sciences, Humanities and Languages, 309 Regent Street, London W1B 2HW, United Kingdom

a.paya1@westminster.ac.uk
\end{abstract}

\title{
Muslim Philosophies: A Critical Overview ${ }^{1}$
}

\begin{abstract}
This paper aims to present a critical overview of the development of philosophical schools founded by Muslim thinkers in the context of Islamic civilisation. The emphasis of the paper is mostly on the reasons and causes of uneven development of this intellectual tradition in Muslim countries. I shall develop my arguments from within the philosophical framework of critical rationalism. While the views of various Muslim philosophers will be critically, though briefly, assessed, the role of other Muslim scholars such as theologians (mutakallimun), mystics ("urafa and Sufis) and jurists (fuqaha) in facilitating or hindering the harmonious growth of Muslims' philosophical heritage will also be touched upon.
\end{abstract}

\section{Keywords}

Muslim philosophies, critical rationalism, Mashshaee (Peripatetic) School, the School of Shiraz, anti-philosophy trends

\section{Introduction}

As a critical rationalist, I regard philosophy as an intellectual pursuit to explore and understand those aspects of reality which empirical sciences, or other human cognitive tools, cannot investigate. ${ }^{2}$ The above view of philosophy is, therefore, in contrast to other views, which regard philosophy to be a "language game" or an activity with "therapeutic purposes" only, or a tool for "domination and subjugation". In my view, philosophies are developed in response to the challenges introduced to people by reality. If the cultural ecosystem in which those challenges have arisen is rich enough, it can pave the way for the emergence of sophisticated philosophical systems.

Fortunately for Muslims, the Qur'an and the tradition of the Prophet and, in the case of the Shi'i Islam, also the traditions of Shi'i Imams are full of

1

A much longer version of this paper, entitled "Islamic Philosophy: Past, Present, and Future”, has appeared in: Anthony O’Hear (ed.), Philosophical Traditions (Royal Institute of Philosophy Supplements, Vol. 74), Cambridge University Press, Cambridge 2014, pp. 265-321. The present paper, apart from being a somewhat condensed version of the above paper, differs slightly in certain junctures from it.
2

For a brief account of the way critical rationalists view philosophy cf. Karl Popper, "How I See Philosophy", in: In Search of a Better World: Lectures and Essays from Thirty Years, Routledge, London 1994. For a more detailed explanation of various tenets of critical rationalism see David Miller, Out of Error, Ashgate, Surrey: 2006. 
instructions which are conducive for constructing a rich intellectual environment. There are many verses in the Qur'an in which Muslims are instructed to use their reason as their guide in exploring reality, studying natural phenomena, understanding various aspects of reality, and enriching their knowledge of God. The Qur'an has also reserved some of its harshest admonitions for those who do not use their intellects. ${ }^{3}$

These internal resources, however, as we shall see later, were further enriched, when Muslims embarked on a mission of digesting and incorporating into their own internal resources, wisdoms of other cultures.

As for the challenges, perhaps, the first intellectual challenges presented themselves to the early Muslims in the shape of political disputes concerning the issue of the succession of the Prophet who died in 632. The question which demanded a satisfactory answer was how Allah would want the believers to go about the task of choosing their political authority. In their efforts to respond to this question, early Muslims were divided along different doctrinal lines; Sunnis, Shi'as, Kharijites, and Murji'ah were among the first sects which appeared in the newly established Muslim society. ${ }^{4}$

The above political question soon gave rise to troubling theological questions concerning the standards which would demarcate a true believer and would determine the after-life station of those who would fall short of (a part of) those standards. Out of these disputes and in the second half of the first century Hijri (according to Islamic calendar; 7th century CE) the first abstract problem, which was a bridge between theological issues and genuine philosophical problems, emerged. The problem in question was the dilemma of the free will and pre-destination (qadar) which, naturally in the context of a religious culture, was related to the issues of Divine justice and Divine power. ${ }^{5}$

Two rival schools of kalam (theology) namely the Ash'arites and the Mu'tazilites were developed in response to the above problem. The Ash'arites maintained that God's omnipotence means that He directly intervenes in all aspects of the whole realm of being. The Mu'tazilites, on the other hand, argued for man's free will. They maintained that God has endowed human beings with the power of intellect, which they regarded as man's inner prophet. Man, according to the Mu'tazilites, was free to choose his path and station in life. ${ }^{6}$

For almost two centuries, and before the emergence of systematic philosophical approaches amongst Muslims in the 9th century CE, it was the mutakallimun (theologians) who dealt with issues which were philosophical in nature.

Early Muslim theologians, however, were not in favour of imported philosophical ideas. In particular they were against the Greeks' philosophical thoughts. They even rejected Aristotelian logic since they regarded it to be an anti-religious knowledge, like Aristotelian philosophy.

But later generations of theologians (mutakallimun) realised that without logic they were prone to commit mistakes in arguments. They adopted Aristotelian logic and applied it to theological as well as philosophical arguments. This approach gradually paved the way for a closer relationship between kalam and philosophy.

\section{First Muslim philosophers}

The translation of scientific, mathematical, technological, cultural, and philosophical achievements of ancient civilisations like the Greeks, the Indians and 
the Persians into Arabic, provided the educated Muslims of the classic period of Islam (9th-13th centuries CE) with a rich intellectual heritage. They soon managed to digest and internalise what they had learnt through these sources and embarked on developing new synthetic systems which were novel innovations informed by their newly gained knowledge through translated materials and in tune with the teachings of their religion. The availability of the riches of the wisdoms of other civilisations enabled Muslim philosophers to enter into a virtual and fruitful dialogue with their non-Muslim counterparts in other cultures.

All great Muslim philosophers of the classic period were not only first rate thinkers with regard to abstract philosophical topics, they were also excellent natural scientists or master technologists.

Even a quick glance at the fields of expertise of Muslim philosophers of the classic period reveals the extent to which these scholars had combined philosophical thinking with other disciplines. For example, Al-Kindi (d. 873), the first Muslim philosopher, was also an astronomer, a physicist, a mathematician and a cryptographer; Farabi (d. 951), ${ }^{7}$ who was known as "the second teacher after Aristotle", was a logician, philosopher, chemist, psychologist, physicist, political philosopher, and musicologist; Abu Rayhan Biruni (d. 1048) was an astronomer, a historian, botanist, pharmacologist, geologist, philosopher, mathematician, and geographer; Ibn Sina (d. 1037) was a logician, philosopher, physician, chemist, geologist, psychologist, an astronomer, and a philosopher of science; Ibn Rushd (d. 1198) was a philosopher, physician, physicist, an astronomer, and a psychologist; Nasir al-Din Tusi (d. 1274) was an astronomer, a physicist, chemist, mathematician, and logician. ${ }^{8}$

Being at home with respect to both philosophy and sciences of the day had enabled Muslim philosophers to apply their power of intellect to a wide variety of real problems in different intellectual and practical fields.

3

See Morteza Motahari, Ashnaei ba 'ulum-e Eslami [An Introduction to the (Classical) "Islamic Sciences"], Sadra Publications, Tehran 1979 (new edition: ICAS Press, London 2016)

4

The first two sects gradually turned into the two largest sects in Islam which exist today and each are divided into a number of subsects. The latter two sects did not last long, though their ideas are still present in the intellectual ecosystem of Islamic doctrine. The Kharijites advocated a very strict adherence to their own literal reading of shari'a law and were intolerant and inflexible in imposing their desired order. The Murji'ah, on the other hand, were of the view that, one should not condemn even the most corrupt and cruel individuals who regard themselves as Muslim. Only God can pass judgement on their fate. Cf. Khalid Blankinship, "The Early Creed", in: The Cambridge Companion to Classical Islamic Theology, ed. by Tim Winter, Cambridge University Press, Cambridge 2008, pp. 33-54, doi: https://doi.org/10.1017/ cco19780521780582.003; Majid Fakhry, $A$
History of Islamic Philosophy, Columbia University Press, New York - Chichester 2004, Ch. 2.

5

See Morteza Motahari, 'Adl-e Elahi [Divine Justice], Sadra Publications, Tehran 1973; Harry Austryn Wolfson, The Philosophy of the Kalam, Harvard University Press, Cambridge, MA - London 1976; M. M. Sharif (ed.), A History of Muslim Philosophy, Otto Harrassowitz, Wiesbaden 1963, Book Three, Part 1, X \& XI, pp. 199-243.

6 See Morteza Motahari, Ashnaei ba 'ulum-e Eslami.

7

I refrain from using the definite article, 'al', before the name of non-Arab scholars. 8

See M. M. Sharif (ed.), A History of Muslim Philosophy; Seyyed Hossein Nasr, Oliver Leaman (eds.), History of Islamic Philosophy, Routledge, London - New York 1996. 
Muslim philosophers developed an approach to learning which can be dubbed 'religious humanism'. It was based on the idea of cultivating individuals through teaching them various sciences and good habits so that they acquire a personal quality which is called $a d a b$, a concept very close to the Greek notion of paideia. According to philosophers, the path to true education ( $a d a b$ haqiqi) was only through philosophy (i.e. rational deliberation).

The outcome of the intellectual efforts of Muslim philosophers and scholars during the Golden age of Islam was not only greatly beneficial to the flourishing of Islamic civilisation, but also provided European scholars with a rich reservoir of fresh ideas.

Many of the works of Muslim scholars, philosophers, scientists, and theologians were translated into Latin. Their counterparts in Europe greatly benefitted from the fruits of the intellectual labour of their colleagues in the Muslim world.

But while the Latin West was benefiting from the views of Muslim thinkers and foundations for the Renaissance were gradually being laid, a dynamics of a different type was at work in the land of Islam.

\section{Decline of scientific spirit in Islamic civilisation}

Despite all the emphasis in the Qur'an and the tradition of the Prophet and Imams (in the case of Shi'i Islam) on the importance of acquiring and developing knowledge, the scientific and philosophical spirit in Islamic civilisation took a nose dive and experienced a gradual decline from the twelfth century onward.

The dominance of the Ash'ari thought provided grist for the mills of those who maintained that Islam is a self-sufficient system in every respect, including knowledge production. The gradual but consistent and continuous ascendency of fuqha (jurists), 'urafa (mystics), and theologians (mutakallimun) of Ash'ari persuasion helped to create an intellectual environment in which rational thinking and scientific pursuits were regarded as either non-Islamic or not suitable for the believers and alien to the spirit of Islam.

By the time of the great Persian Ash'ari jurist, sufi-saint, and theologian (mutakallim), Abu Hamed Mohammad Ghazzali (d. 1111), the orthodoxy was firmly in place in all parts of Muslim lands in which one of the four Sunni schools of fiqh was being practiced.

Having declared philosophy as an unsuitable subject for study in the ecosystem of Islamic culture, Ghazzali, in his magnum opus, Ihya al-ulum aldin (Revival of the Religious Sciences) which is an encyclopaedia of Islamic sciences of his day, introduced a new classification of sciences. He divided sciences into two general groups, religious and non-religious, and made clear that only the first group has an intrinsic value. ${ }^{9}$

The tendency of placing religious sciences on a higher plane than non-religious sciences was further amplified in the works of Muslim mystics (' $u r f a$ ) and Sufis. In their teachings, non-religious sciences were regarded as tools and instruments whose purpose was to help Muslims in this life to dedicate themselves to the study of truly worthwhile sciences, i.e. non-religious, and in particular 'irfani sciences.

The closing of the door of ijtihad among the Sunni Muslims dealt another severe blow to the spirit of critical thinking in Islam. ${ }^{10}$ 
To the above intellectual trends, social and political upheavals in Muslim countries should be added. Each one of these trends dealt a severe blow to the flourishing intellectual ecosystems in Muslim countries. The animosity between the Abbasid dynasty (750-1258) in Baghdad and the Fatimid dynasty (909-1171) in Egypt, the Crusades (1095 and 1291), the invasion of the Moghuls, Hulago Khan (1218-1265) and later Taymour (Tamerlane, 13361405) all helped the creation of an environment which was not amenable to free and critical thinking. The result was that philosophy as a discipline and a tradition died a sudden death among the Sunni Muslims in the eastern flank of Islamic civilisation. Philosophical thinking, however, did not die away among Muslims. It followed two different paths in the Eastern and Western parts of Muslim lands. In Spain, Muslim philosophers such as Ibn Bajjah (1095-1143), Ibn Tufayl (1105-1185) and Ibn Rushd (1126-1198) continued the Mashsha' $i$ (Peripatetic) tradition. However, with the collapse of Muslim dynasties in Spain in the late fifteen century, development of Islamic philosophy ${ }^{11}$ in the Sunni Islam came to an end and the philosophical spirit vanished from its ecosystem. In the Eastern flank of Islamdom philosophy survived among Muslim scholars from Iran. It is to this development that we now turn.

\section{Al-Hikmat al-Mashreqiyah and the emergence of novel systems of theosophy}

A closer look at the development of philosophical thought in Islam makes it clear that kalam and irfan have always had some sort of influence on rational approaches to philosophising and philosophers have always been acutely aware of the need for addressing the concerns of not only theologians ( $m u$ takallimun) and mystics ('urafa), but also jurists (fuqha).

A case in point is the Persian philosopher Ibn Sina, who is undoubtedly the greatest Peripatetic philosopher in the tradition of Islamic philosophy, and yet, despite all his penchants for rational approaches later in his life and in his later works, he laid down the foundations of an intellectual legacy which turned into the dominant trend of thought among subsequent generations of Muslim philosophers.

Ibn Sina's influential legacy was the development of an entirely new school of thought which he dubbed al-Hikmat al-Mashreqiyah (the Eastern philosophy). The main characteristic of this new school was its emphasis on the power of intuition and mystical experiences, as against rational thinking as the most effective tool for exploring reality and acquiring knowledge about it.

Al-Hikmat al-Mashreqiyah was further developed into a comprehensive philosophical system by another great Persian philosopher, Shahb al-Din

See Ghazali, Revival of the Religious Sciences [Ihya'ulum al-din], Book 1: "The Book of Knowledge", trans. by Nabih Amin Faris, Islamic Book Service, New Delhi 1979, p. 30 This text is available online at: http://www. ghazali.org/site/ihya.htm.

10

See Joseph Schacht, An Introduction to Islamic Law, Oxford University Press, Oxford 1982.
11

I use the term 'Islamic philosophy' in a neutral way, meaning philosophical doctrines produced by thinkers who happen to be either Muslim or living in Muslim countries or both. This term can be used interchangeably with a similar term, 'Muslim philosophy', throughout this paper. 
Suhrawardi (1158-1191), the founder of Maktab-i Ishraq (the School of Illumination). ${ }^{12}$

Suhrawardi's system was a novel synthesis of various trends of thought, including Platonic and neo-Platonic ideas, doctrines from the wisdom of ancient Persian sages (Hukamaye-Pahlavi), doctrines extracted from the Qur'an and the teachings of the Prophet. ${ }^{13}$

In his captivating works both in Persian and Arabic, Suhrawardi developed a complete metaphysical system based on the notion of light and its contrast with darkness. God was the 'light of lights'. Suhrawardi narrated an epic story on a metaphysical plane whose main hero was man who had fallen from the realm of light into the realm of darkness and was longing to get back to his origin.

Suhrawardi had a profund influence on almost all the subsequent generations of Muslim philosophers. From Suhrawardi onward, Islamic philosophy, in a systematic fashion, dedicated all its attention to theosophical issues, i.e. issues related to understanding God and His manifestations by means of rational argumentation, intuition and mystical experiences. It took as its main sources of exploration and investigation, the holy Qur'an, and the teachings of the Prophet and the Shi'i Imams.

The teaching of Sufis and mystics, especially with regard to notions such as vali (friend, guardian, pl. ulia') and vilayat (friendship, guardianship), topics which were frequently discussed in Suhrawardi's books, also heavily influenced the future development of philosophy in Iran. A Sufi-saint whose views was very influential in this respct was Ibn Arabi (d. 1240). ${ }^{14}$

\section{Philosophical developments in the sixteen and seventeen centuries: Schools of Isfahan and Shiraz}

The intellectual trend towards combining mystical, gnostic, and illuminationist insights with Qur'anic and Prophetic teachings and rational thinking reached its zenith in two influential philosophical schools with distinct Shi'i flavour, namely the School of Isfahan and the School of Shiraz. The emergence of both of these schools was greatly facilitated, if not became possible in the first place, because of the coming to power of the Safavids dynasty in Persia (1501-1736).

The founder of the School of Isfahan was Muhammad Baqir Damad (d. 1631), better known as Mir Damad. ${ }^{15}$

Mir Damad's main project was to develop a system of philosophy based on the wisdom revealed by God to the prophets, known as the Yamani wisdom (Hikmat-i Yamani) in contrast to the rationalist philosophy of the Greeks. The title of Mir Damad's system was apparently inspired by a Prophetic hadith (tradition), namely, "al-imanu al-Yamani va al-Hikmatu al-Yamaniyatu" (the true faith is the Yamani faith and the true wisdom is the Yamani wisdom). ${ }^{16}$

In the dispute among Muslim philosophers concerning the status of existence (wujud) and quiddity (mahiyyat) in the grand scheme of things, Mir Damad argued against Ibn Sina (in his Peripatetic phase) by endorsing the principality of quiddity (mahiyyat) and the accidental nature of existence (wujud). Among his philosophical innovations the notion of huduth-i dahri (a temporal creation or emergence) - which he contrasts with two other notions, namely, huduth-i zamani (temporal creation or emergence) and huduth-i dhati (essen- 
tial contingency) - deserves to be mentioned. He maintained that all entities, apart from God, i.e. all contingent beings, have an unchanging existence in a realm which is called dahr (aeon). God is outside of this realm, his existence is sarmadi (without beginning and end). According to Mir Damad, all temporal beings, in any moment of their existence, have a dahri counterpart. Dahr acts as a cosmic memory in which whatever is in God's mind has a copy.

Mir Damad was able to provide solutions for a number of philosophical as well as theological issues, including the problem of 'createdness of time', 'rejection of the Platonic realm of Ideas', the issue of God's foreknowledge, and the changes $\mathrm{He}$ effects in the grand design of things (naskh va bada'). ${ }^{17}$

Islamic philosophy in the tradition of combining gnostic, religious, and rational strands, reached its apex in the teachings of Sadruddin Muhammad Shirazi (1571-1640), better known as Akhund Mulla Sadra and also as "Sadr Al-muti'allihin" (the foremost amongst the theosophians). Mulla Sadra was contemporaneous with Descartes and was as influential philosopher in Islamic culture as was Descartes in the context of European thought. However, the approaches of these two intellectual giants were poles apart. Mulla Sadra dedicated his whole intellectual energy to the development of, perhaps, the finest theosophical system ever introduced within the econiche of Islamic culture. He, like his predecessors in the gnostic tradition, maintained that the only worthwhile knowledge is theosophy. He explicitly criticised Ibn Sina for wasting his time on Peripatetic philosophy and medicine.

Mulla Sadra's exquisite system in which rational thinking was combined with esoteric approaches and applied to the teachings of the Qur'an and the tradition of the Prophet and the Shi'i Imams, came to be known as Hikmat alMuti'aliyeh (the Transcendent Theosophy).

Like Suhrawardi and Mir Damad before him, Mulla Sadra presented a complete metaphysical system which provides explanation for every aspect of reality, whether God, angels, man, afterlife, the day of judgement, and so on. His system, however, in contradistinction to the systems developed by his two eminent predecessors was based on the notion of existential primacy (taqad-

12

For Suhrawadri's life and work see Seyyed Hossein Nasr, Three Muslim Sages: Avicenna, Suhrawardi, Ibn 'Arabi, Harvard University Press, Cambridge 1964. For a comparison between Suhrawardi's and Ibn Sina's philosophies see Mehdi Aminrazavi, "How Ibn Sinian Is Suhrawardi's Theory of Knowledge?", Philosophy East and West, Vol. 53 (2003), No. 2, pp. 203-214, doi: https://doi. org/10.1353/pew.2003.0010.

13

See Shahabuddin Suhrawardi, Philosophy of Illumination [Himkmat al-Ishraq], trans. by John Walbridge and Hossein Ziai, Brigham Young University Press, Provo, UT 1999; Shahabuddin Suhrawardi, The Shape of Light [Hayakal al-Nur], trans. by Shaykh al-Halveti, Fons Vitae, Louisville, KY 1986.

14

For Ibn Arabi's life and work see William C. Chittick, Ibn 'Arabi: Heir to the Prophets, One World, Oxford 2005.
15

For Mir Damad's life and work see Hamid Dabashi, "Mir Damad and the Founding of the School of Isfahan", in: S. H. Nasr, O. Leaman (eds.), History of Islamic Philosophy, Ch. 34, pp. 597-634.

16

See Zahra Mostafavi, "Dahr (the Meta-Time), the Main Element in Hikmat Yamani (the Mir Damad's Philosophy)", Journal of Religious Thought, No. 22, 2007, pp. 21-39.

17

See Fazlur Rahman, "Mīr Dāmād's Concept of Hudūth Dahrī: A Contribution to the Study of God-World Relationship Theories in Safavid Iran", Journal of Near Eastern Studies, Vol. 39 (1980), No. 2, pp. 139-151, doi: https://doi.org/10.1086/372791. 
dum rutbi) of being (wujud) over quiddity (mahiyyat) or the principality (i.e. reality) of being and accidentally (non-reality) of quiddity.

In the realistic outlook of Mulla Sadra the whole realm of being consists of just one reality, namely God. All the rest are His manifestations and, therefore, have no genuine reality on their own. God is the only necessary being, all the rest are contingent entities. For this particular type of contingency Mulla Sadra coined a new term, imakan-i faqri (contingency due to existential dependence) which was different from the common notion of contingency, namely, imkan-i mahuwi, contingency related to the quiddity or essence, which was used by previous philosophers. ${ }^{18}$

Mulla Sadra introduced many novel themes and theories into Islamic philosophy and provided convincing solutions for many outstanding problems in not only the field of philosophy, but also theology and mysticism.

I will not be able to do justice to Mulla Sadra's numerous and rich achievements. Perhaps a few words concerning his theory of 'substantial motion' may provide a flavour of his approach. For Mulla Sadra, the primacy and principality of existence, means, among other things, that each entity has a personal or individual identity. Existence ought to be contrasted with nonexistence. The more perfect an entity the richer its existence, in the sense that it is less contaminated with non-existence or mixed with it. For non-material entities, their imperfection manifests itself in their absolute dependence upon God for their existence. But in the sub-lunar realm, which is the abode of material entities, imperfection obtains an added feature. Here, the degrees of actuality and potentiality determine the degree of perfection of a particular entity with regard to its particular identity.

In this context, change means turning potentiality into actuality. Mulla Sadra argues that individual beings in the sub-lunar realm, which each have their own distinct identities, experience, on a continuous basis, the process of actualisation of their potentialities. This process, first and foremost, happens in the individual's existential substance and, as a result, changes in other categories such as quantity (kamm), quality (kaif), and place (makan) will be effected. Time is also a dimension which displays the above sequence of continuous and seamless turning of potentiality into actuality. Mulla Sadra thus identified time as the fourth dimension of material entities. ${ }^{19}$

The human soul is at the beginning merely a potentiality. Under favourable circumstances, it gradually emerges as a result of the interaction of the body of the newly conceived embryo with the environment. The process of actualisation of the potentials embedded in the soul continues until the last moment the individual is alive and active. Since both the body and the soul have many different potentials, actualising particular aspects of such potentials becomes a matter of interaction between the individual and its environment. At the end of one's life in this world, one's soul leaves one's body and, depending on the degree of perfection it may have achieved while still in this world, it enters the realm of purgatory, or higher up in the chain of being.

In the period after the death of Mulla Sadra, until the twentieth century, Islamic philosophy was mostly a footnote to the Sadraean system.

\section{A brief account of two major developments in Islamic philosophy in the 20th century}

In the early decades of the twentieth century, Iranian left-wing intellectuals, like their counterparts in other parts of the world who were inspired by the 
Bolshevik revolution in Russia, embarked on an ideological crusade to promote various aspects of Marxism-Leninism, and in particular dialectical materialism in Iran. These efforts received a great boost in 1941 with the formation of the Soviet backed Tudeh Party.

In reply to this ideological onslaught, one of the greatest masters of Islamic philosophy in modern times, Allameh Seyyed Muhammad Hussein Tabatabaee (1904-1981), decided to expose the shortcomings of the Marxist ideology by critically assessing its philosophical doctrines. In the mid-1950s, Allameh began teaching a course of philosophy to a selected group of clerics chosen from among his best students. This course, based on twice-weekly sessions, lasted for about three years. During this period many philosophical aspects of Marxism and dialectical materialism were discussed. Allameh's lecture notes were edited and heavily annotated by his best disciple, Ayatollah Morteza Motahari (1920-1979), a renowned philosopher in the tradition of Islamic philosophy, and published in five volumes, under the general title of The Principles and Method of the Philosophy of Realism.

This work, whose content I am going to briefly, though critically, discuss in this section, marked a watershed, though unfortunately not a turning point, in the long-standing tradition of Islamic philosophy. It was a watershed in the sense that after centuries of inward-looking, Muslim philosophers applied their talents and also the machinery of Islamic philosophy to a problem outside the usual set of theosophical problems. It did not, however, turn into a turning-point, in that it remained as, more or less, a one-off project. It did not give rise to systematic application of Islamic philosophy to other newly emerged issues in the Islamic communities.

The Principles and Method of the Philosophy of Realism consists of fourteen "articles", each dealing with one important philosophical topic. The two ayatollahs, Tabatabaee and Motahari, did a thorough job in exposing the epistemological shortcomings of Marxism and dialectical materialism. For example, they argued that the Marxists' theory of knowledge leads to relativism and, therefore, fails to provide universal knowledge of reality. Dialectical materialism is also problematic in that accepting only one contradiction leads to an untenable epistemic position in which all sorts of bizarre claims can be made without any way to examine them.

In addition, for the first time in the history of Islamic philosophy and almost two decades before David Lewis' Convention: A Philosophical Study (1969) and four decades before John Searle's Construction of Social Reality (1995) this work discussed the idea of knowledge about e'tebariyat, conventions, and those socially constructed realities whose function is to respond to man's non-cognitive needs, as against his cognitive needs which are taken care of

18

Mulla Sadra presented his metaphysical system in its developed form in his magnum opus, al-Asfar al-Araba'a [The Four Journeys], Entesharat-e Bonyad Hikmat Islami Sadra, 9 vols., Tehran. Partial translations of this work are available. For example, Latimah-Parvin Peerwani has translated the fourth intellectual journey: Mulla Sadra, Spiritual Psychology, ICAS Press, London 2008.

19

See Mulla Sadra, al-Asfar al-Araba'a, First, Third and Fourth Journey. Mulla Sadra's theory of the human soul allows him to offer a novel solution for the vexed issue of the mind-body problem. Since the soul emerges from the body and remains in touch with the body until the end of an individual's life, the usual difficulties which beset a Cartesian model do not affect his model. For a modern reconstruction of Mulla Sadra's theory of substantive motion see Abdolkarim Soroush, $\mathrm{Na}$ had-e Na Aram-e Jahan [The Never-resting Nature of the Cosmos], Muassesseh Farhangi Serat, Tehran 1999. 
by science/knowledge. Allameh introduced a highly original and detailed account of the structure of knowledge of conventions of all sorts. He divided the e'tebariyat into pre-social and post-social. The first group were, in Searle's parlance, products of individual volitive intentionalities, whereas the second group were products of collective volitive intentionalities. ${ }^{20}$

The aim of Allameh Tabatabaee was to refute the epistemic doctrines of Marxists who tended to present their views as "scientific" and objective and did not seem to be aware of the fact that, by linking the individual's knowledge of reality to social classes, their theory of knowledge loses all its objective credibility. He also intended to expose the Marxist fallacy of presenting socially constructed entities and the knowledge thereof as absolute and indubitable truth about material reality.

However, Allameh did not limit his criticism only to Marxist doctrines; he also challenged the approaches of fugha (Muslim jurists) who, according to Allameh, had not differentiated between the normative status of the views they had discussed in their legal discussions and factual claims about reality.

Another important development in the field of Islamic philosophy in the twentieth century was due to a young Iraqi mujtahid, Mohammad Baqir Sadr, who had been trained in the Sadraean school of thought and was well familiar with Allameh Tabatabaee's views, and intended, like Allameh, to make use of the machinery of usul al-fiqh ${ }^{21}$ in developing new vistas in Islamic philosophy.

Ayatollah Sadr, who was executed along with his sister by the Baath regime in Baghdad, reportedly by Saddam Hussein's direct order, in April 1980, like Ayatollah Mutahari was concerned about developing a proper philosophical response to the challenges presented by Marxism and other foreign ideologies or philosophical systems. Like Ayatollah Motahari, he also maintained that the intellectual facilities available in Islamic culture could help researchers to develop systems of thought which are free from the defects of Western philosophical schools. Also, like Ayatollah Motahari, he produced many books in response to modern challenges.

However, his masterpiece was published in 1977. In a trailblazing and influential book, al-Ussus al-Mantaqiyah li'l Istiqra' (The Logical Foundations of Induction), he took upon himself to develop an epistemological system based on the resources available in the Islamic intellectual milieu in order to suggest a solution to the vexed problem of induction. ${ }^{22}$ The title of the book was, however, a misnomer, since the author had no intention of providing logical foundations for induction and maintained that no such foundations can be found.

For developing his novel and critical assessment of the problem of induction, Ayatollah Sadr, on the one hand, relied on the Arabic translation of Bertrand Russell's Human Knowledge, and, on the other hand, made use of his detailed knowledge of usul al-figh and of Islamic philosophy. He criticised the solution proposed by Aristotle and also Mashsha' $i$ philosophers for the problem of induction, arguing that the principle of uniformity of nature, or its variances used by Aristotelians to justify induction, is not self-evident. It relies on induction. ${ }^{23}$

Ayatollah Sadr then criticised Hume's and Mill's arguments. He rejected Hume's claim that causality cannot be established by empirical evidence and also rejected his pessimism concerning the impossibility of finding a solution for the problem of induction. As for Mill's view, he noted that, while Mill was right in thinking that causality can be established by inductive means, he was wrong in linking the validity of inductive generalisation to causality. 
Having explained the failure of some of the well-known approaches to the problem of induction, Ayatollah Sadr introduced his own epistemological approach which he maintained could solve the problem once and for all. Ayatollah had dubbed his novel theory Al-Nazariyah al-Tavalud al-Dhati fi al-Ma'refat al-Bashariyah (The Theory of Inherent Proliferation in Human Knowledge).

This novel theory is based on two pillars; namely, particular notions of certainty and a particular interpretation of probability developed in the light of an usuli concept. According to Ayatollah Sadr there are three types of certainties, namely: logical certainty, inherent certainty (al-yaqin al-dhati), and objective certainty (al-yaqin al-mawduee). Logical certainty pertains to the necessary relations between the conclusion of a valid syllogism and its premises and also necessary relations between subjects and predicates of tautologies. Inherent certainty refers to a subjective, psychological type of certainty. But the last type of certainty is achieved on the basis of accumulation of external evidence and the strength of this evidence.

As for his particular interpretation of probability, he introduced a model in which a well-known notion from usul al-fiqh, namely, al- ilm al-ijmali, which literally means 'un-detailed knowledge', was carefully crafted with some aspects of the classic (Laplacian) and the frequency (von Mises) theories of probability without incorporating their weaknesses. The Ayatollah defined al- 'ilm al-ijmali in the context of his own theory of probability as "certain knowledge about an unidentified member of a certain set".

The Theory of Inherent Proliferation in Human Knowledge, which is in itself extremely interesting, since it shows how a traditional mujtahid and philosopher is grappling with an immensely important philosophical issue, boils down to the following claims for each of which the author provides detailed arguments:

(1) One begins one's knowledge pursuit about a particular subject-matter on the basis of a degree of al-ilm al-ijmali about it. This is our opening hunch or conjecture. Some sort of relation of entailment exists among various parts of one's subjective knowledge which is the realm of subjective certainty. This knowledge can be expanded in a piecemeal manner by gradual increase in one's degree of rational belief.

(2) One's degree of rational belief concerning a particular subject-matter, based on al-ilm al-ijmali about that subject-matter, can be increased by the application of induction. At this stage, due to accumulation of relevant

20

I critically assess Allameh's views on e'tebariyat in "A Critical Comparative Assessment of Allameh Tabatabaee's Theory of e'tebariyat, David Lewis's Convention and John Searle's Construction of Social Reality" (2016 forthcoming).

21

Usul al-fiqh (the principles of fiqh) is a semantic and hermeneutical machinery which assists fuqha (jurists) in their dealings with semantic entailments of the verses of the Qur'an and the traditions of the Prophet and Imams. Its relation to fiqh (Islamic jurisprudence) is somewhat like the relation of logic to philosophy.
22

S. M. B. Sadr, al-Ussus al-Mantaqiyah li'l Istiqra, Dar al Ta'aruf li'l Matbu'at, Beirut, fourth imprint, 1977/1982.

23

The first Muslim philosopher who critically and thoroughly discussed Ayatollah Sadr's theory of induction was Abulkarim Soroush, "Mabni Mantiqi Istiqra' az Nazr-e Ayatollah Sadr" [The Logical Foundations of Induction from Ayatollah Sadr's Point of View], Nashr- $i$ Danish, No. 15, 1983, pp. 22-43. I have heavily relied on his article in developing this part of the present paper. 
evidence, one's objective certainty concerning the subject-matter under study also increases. This stage is called the 'stage of objective proliferation of knowledge' (al-tawalud al-mudu' $i$ ).

(3) In the last stage, which is called the 'stage of inherent proliferation of knowledge' (al-tawalud al-dhati), increase in the degree of probability and in objective certainty combined with certain rules of entailment leads to the transformation of our initial conjecture into 'inherent certainty' ( $a l$ yaqin al-dhati) concerning the subject-matter of our research.

Ayatollah's Sadr's new subjective theory of induction, of course, as some Muslim philosophers have argued, ${ }^{24}$ like all other suggested solutions for this problem, fails to achieve its goal. Nevertheless, his bold efforts in developing, perhaps for the first time in the modern history of Islamic philosophy, a novel approach which radically enlarges the horizon of traditional thinking is worthy of praise.

\section{Some of the major shortcomings of traditional Islamic philosophy}

In the light of developments in modern epistemology and metaphysics, it seems the traditional Islamic philosophy, as taught in religious seminaries and some modern universities in Muslim countries, suffers from a number of shortcomings. The following is a brief critical assessment of these weaker points in the approaches of traditional Muslim philosophers.

In the first place and from a methodological point of view, it seems that the intellectual activities of many of the practitioners in traditional Islamic philosophy are less problem-oriented and more directed towards transmission and exposition of the views of past masters. Meeting the challenges posed by newly-emerged problems is not high on the list of intellectual priorities of many of the traditional practitioners of Islamic philosophy.

Three other evident shortcomings of traditional approaches to Islamic philosophy are: adherence to self-evident truths as the justificatory basis of all knowledge claims; strong emphasis on attainment of certainty as the end goal of epistemic pursuits; and insistence on the so-called 'ilm-I huduri' (knowledge-by-presence) as the ultimate and most valuable type of knowledge.

However, subscription to the above three theses, as I briefly argue here, deprives Islamic philosophy from ridding itself from the shackles of a dogmatic outlook. Of the three theses introduced above, perhaps the second one, i.e. an emphasis on attaining certainty, is the most important one. It seems such an emphasis on the role of certainty and its place in philosophical investigations is not unrelated to religious teachings in which the strength of believers' faith is gauged by their degree of certainty in God and in the truth of Islamic teachings.

The notion of certainty, yaqin, is also emphasised in many of the Qur'anic verses. To make things even more complicated, the Qur'an introduces three different notions of yaqin, which imply a hierarchy or various degrees of certainty. These are known as ilm al-yaqin (the knowledge of certainty $=$ certainty due to acquired knowledge), 'ain al-yaqin (the eye of certainty = certainty obtained through direct encounter / direct 'visual' evidence), and haq al-yaqin (the truth of certainty $=$ absolute, indubitable certainty). ${ }^{25}$ 
Now it seems these degrees of certainty are contrasted to epistemic concepts such as shakk (doubt), zann which is translated into 'surmise' and 'conjecture', and wahm (phantasm).

Perhaps prior to the introduction of the views of critical rationalists such as Karl Popper and David Miller, almost all Muslim scholars were, and the majority of them still are, of the view that certainty is an epistemic state and failing to obtain it implies not only a serious defect in one's epistemological approach, but more worryingly weakness in one's faith in God. It seems the majority of Muslim scholars, including most, if not all, Muslim philosophers, never considered the case that certainty is not an epistemic state but a psychological one, and that knowledge can be attained by means of constructing conjectures and projecting them into reality. ${ }^{26}$

Apart from a general understanding of the meaning of the concept of yaqin in the context of Islamic culture and its value and worth in the eyes of Muslims, it seems that Muslim philosophers, who have always been accused by their fellow theologians, jurists, and mystics of introducing ideas and views which are alien to genuine Islamic teachings, have been extra careful to emphasise the importance of yaqin and also the fact that their philosophical systems are capable of achieving it.

However, the emphasis of various schools of Islamic philosophy on their ability to attain certainty as the end goal of their epistemic pursuit has not helped the position of these schools in the eyes of their opponents. These opponents, each in their own way, maintain that certainty can be obtained with much more effectiveness and greater ease through their own way rather than moving along the torturous path of incomprehensible philosophical reasoning.

The literalists, of different types and orientations among both the Sunnis and the Shi'as, represent one such opponent group. They claim that certainty can be attained by closely following the Sharia law. The second group, also of large variety, are the Sufis who advocate mystical practices, in place of rational arguments, as the best way of acquiring certainty.

In their pursuit of achieving certainty, it seems that Muslim philosophers have fallen into the trap of yet another category mistake: they have mistakenly upheld the notion of $i l m-i$ huduri, 'knowledge by presence', as an epistemic notion. This notion is also referred to as the outcome of a process known as itihad-i 'aqil va ma'qul (the unity between the intellect and the intelligible) or itihad-i 'alim va ma'lum (the unity between the knower and the known). This process and its end result refer to an existential experience and a state of being and becoming and not an epistemic state in which we use language and concept to reconstruct our lived experiences.

The insistence of Muslim philosophers on basing their philosophies on the foundation of self-evident truth and seeking justification for their knowledgeclaims by resorting to this notion has also made their systems vulnerable to

24

See Soroush's paper introduced in the previous footnote. Some other Muslim philosophers have also produced critical assessments of Ayatollah Sadr's views on induction.

25

See the Qur'an, 102:5\&7, 56:95, 69:51.
26

I have discussed this issue in a number of papers including "A Critical Assessment of the Programmes of Producing 'Islamic Science' and 'Islamisation of Science/Knowledge", International Studies in the Philosophy of Science, Vol. 30 (2016), No. 1, pp. 311-335, doi: https://doi.org/10.1080/02698595.2015.1 $1790 \overline{043}$ 
all criticisms levelled at the validity of self-evident notions and the process of justification. ${ }^{27}$

\section{The future of Islamic philosophy}

Having swiftly and briefly discussed some of the developments in the field of Islamic philosophy, we should, perhaps, also say something about possible scenarios which one can envisage for the future of this tradition. Of course, talking about future trends is always a risky business. Prediction of the future, as we all know, is not possible. I am not, therefore, going to attempt the impossible here. The best I can do is to suggest one or two plausible scenarios for the future development of Islamic philosophy.

The scenarios I envisage for the future are based on my discussion in this paper. In my view, for Islamic philosophy to be able to play an efficient role in tackling real-life issues, it needs to reconnect with science and technology. It should regard science as a genuine companion in its knowledge pursuit, and not as a mere means for futile justificatory purposes. It also needs to realise that 'certainty' does not belong to the realm of knowledge investigation. The spirit of critical and rational thinking, openness to ideas and views developed in other cultures and civilisation, and tolerance which was once strong among Muslim thinkers must be encouraged and enhanced once gain. Its choice of problems should also be considerably augmented and enriched by an attitude for combining abstract thinking with applied reasoning.

Now, as far as the philosophical and cultural milieu in Iran is concerned, I can say, with some degree of optimism, that in recent decades, and especially after the Islamic revolution, seeds for a revolutionary change in intellectual and philosophical endeavours have been sown in the country. While in the past, the majority of those young souls who would study philosophy, whether in seminaries or in universities, were, by and large, not academically well-equipped and not particularly apt for this field, but had opted for it out of necessity and not choice, in the years leading to the revolution and after that many talented students with good backgrounds in science, mathematics, and engineering enrolled in philosophy courses. The introduction of modern trends of philosophical thought has also opened up new opportunities for philosophy students, whether in seminaries or in universities, to move beyond the traditional teachings which have been in circulation for a long time.

It will be no exaggeration to claim that the number of philosophy graduates, again whether from seminaries or universities, who are gaining confidence, out of respect for truth and genuine love of knowledge, to combine traditional reverence towards their elders (especially teachers) with critical assessment of their views, is on the increase.

It is also a fact that Iranian students of philosophy are becoming more and more aware of the importance of relatively newly emerged philosophical fields such as applied philosophy. This awareness has helped them to better appreciate the need for adopting problem-oriented approaches in their philosophical endeavours.

The fact that the fuqha (jurists), despite enjoying a privileged status, have come under increasing pressure with regard to their monopoly over "representing" the official face of Islam, has provided further breathing space for the emergence of new, critical trends of thinking in the country. ${ }^{28}$

Another factor which could help the development of a more rational approach to Islamic philosophy in Iran and, perhaps, those other Muslim countries, in 
which philosophy is gradually taking root, is the activities of scholars (especially Western scholars) outside Islamic countries.

Papers and books produced by these scholars, in a way, set some standards with which Muslim philosophers may compare and contrast their own level of scholarship. It must be emphasised that in recent years, and as a result of strong institutional support for scholarly activities in seminaries in Iran and similar support for the promotion of religious sciences, the number and quality of scholarly journals and publications which are dedicated to the elucidation of various aspects of Islamic philosophy has received a considerable boost in Iran.

Given the fact that neither philosophical nor scientific knowledge claims, as against technological techniques and know-how, could be regarded as culture-specific, such a newly developed philosophy could only be regarded as 'Islamic philosophy' in the sense I explicated earlier in this paper, namely, the outcome of intellectual endeavours of individuals who happen to be Muslim or live in Muslim lands or both, and make use of, among many other resources, the intellectual machinery developed in Islamic civilisation. This philosophy, provided it upholds its critical and rational approach, could join forces with other schools developed elsewhere in tackling problems which are regarded as challenges for modern men wherever they happen to be and to whatever sources of inspiration they happen to be attached.

Of course, the above optimistic trends should not be over-emphasised. There are, as there have always been, anti-rational and anti-philosophical tendencies in Islamic societies, in general, and in their centres of learning in particular. A case in point is a relatively new anti-philosophical school, known as makatb-i tafkik (the Separationist School) based on the views of Sayyid Mūsā Zarābādī (d. 1934), Mīrzā Mahdī Gharavī Iṣfahānī (d. 1946), and Shaykh Mujtabá Qazvīnī Khurāsānī (d. 1966). This trend has powerful bases in many traditional seminaries inside and outside Iran and especially in Mashhad. Tafkikis strongly oppose philosophy in all its shapes and forms, even in the sanitised form of Mulla Sadra's Hikmat al-Muti'aliah. In their view, even the Qur'an should be understood by the teachings of the Shi'a Imams. ${ }^{29}$

Nevertheless, it seems to me that new critical trends, within the general framework of 'Islamic philosophy', are slowly but surely moving towards acquiring the critical mass required for making their presence felt. As for an approximate time-scale for reaching such a threshold, I better not hazard making any guess and end my future gazing here.

27

For futility of the 'justificationist' approach see David Miller, "Overcoming the Justificationist Addiction" (2011), available at: http:// www2.warwick.ac.uk/fac/soc/philosophy/ people/associates/miller/wroclaw2b.pdf

28

In a recent paper entitled "Faqih as Engineer: A Critical Assessment of the Epistemological Status of Fiqh", American Journal of Islamic Social Sciences, Vol. 33 (2016), No. 1, pp. 25 51, doi: https://doi.org/10.12816/0037416, I have demonstrated that contrary to a prevailing view, fuqha are not 'ulama (scholars whose aim to acquire knowledge about reality). They are engineers and technologists, i.e. professionals whose expertise responds to people's non-cognitive needs or facilitate, as tools, their knowledge pursuit. But they are not producers of theoretical knowledge.

29

I critically discussed the views of tafkikis in the paper "The Disenchantment of Reason: An Anti-rational Trend in Modern Shi'i Thought - Tafkikis", presented at the Third Annual Conference of the British Islamic Studies Association, London, April 11-12, 2016. 


\title{
Ali Paya \\ Muslimanske filozofije: \\ kritički osvrt
}

\begin{abstract}
Sažetak
Cilj je ovog rada kritički se osvrnuti na razvitak filozofskih škola koje su utemeljili muslimanski mislitelji u kontekstu islamske civilizacije. Naglasak je rada uglavnom na razlozima i uzrocima promjenjivih razvitaka ove intelektualne tradicije u muslimanskim zemljama. Razvijam svoje argumente unutar filozofskog okvira kritičkog racionalizma. Dok se stajališta raznih muslimanskih filozofa ocjenjuju kritički, premda ukratko, spominje se i uloga drugih muslimanskih učenjaka kao što su teolozi (mutakallimun), mistici ("urafa $i$ sufije) te pravnici (fuqaha) u olakšavanju ili priječenju harmoničnog rasta muslimanskog filozofskog nasljeđa.
\end{abstract}

\section{Ključne riječi}

muslimanske filozofije, kritički racionalizam, mashsha'i (peripatetička) škola, širaska škola, antifilozofski trendovi

\section{Ali Paya \\ Muslimische Philosophien: eine kritische Übersicht}

\section{Zusammenfassung}

Diese Abhandlung ist bestrebt, einen kritischen Überblick über die Entwicklung von philosophischen Schulen zu präsentieren, die von muslimischen Denkern im Kontext der islamischen Zivilisation gegründet wurden. Der Schwerpunkt der Arbeit liegt hauptsächlich auf den Gründen und Ursachen der ungleichmäßigen Entwicklung dieser intellektuellen Tradition in muslimischen Ländern. Ich werde meine Argumente aus dem philosophischen Rahmen des kritischen Rationalismus heraus vorbringen. Während die Ansichten diverser muslimischer Philosophen - wenn auch nur kurz - kritisch beurteilt werden, wird ebenso die Rolle anderer muslimischer Gelehrter wie Theologen (mutakallimun), Mystiker ('urafa und Sufis) und Juristen (fuqaha) in der Erleichterung bzw. Beeinträchtigung des harmonischen Wachstums des muslimischen philosophischen Erbes angeschnitten.

\section{Schlüsselwörter}

muslimische Philosophien, kritischer Rationalismus, mashsha'i (peripatetische) Schule, Schiraser Schule, antiphilosophische Trends

\section{Ali Paya \\ Philosophies musulmanes : compte rendu critique}

\begin{abstract}
Résumé
Le but de ce travail est de présenter un compte rendu critique sur l'essor des écoles philosophiques fondées par des penseurs musulmans dans le contexte de la civilisation islamique. L'accent est principalement mis sur les raisons et les causes du développement irrégulier de cette tradition intellectuelle dans les pays musulmans. Mes arguments seront développés dans le cadre du rationalisme critique. Alors que les perspectives de nombreux philosophes musulmans seront évaluées de manière critique, quoique brièvement, d'autres savants seront également abordés tels que les théologues (mutakallimun), les mystiques ("urafa et les soufis) et les juristes (fuqaha) afin de comprendre s'ils ont joué un rôle en faveur ou contre le développement harmonieux de l'héritage philosophique musulman.
\end{abstract}

\section{Mots-clés}

philosophies musulmanes, rationalisme critique, école (péripatéticienne) mashsha'i, école de Shiraz, tendances antiphilosophiques 